This item was submitted to Loughborough's Research Repository by the author.

Items in Figshare are protected by copyright, with all rights reserved, unless otherwise indicated.

\title{
Sen, Marx and justice: a critique
}

PLEASE CITE THE PUBLISHED VERSION

http://dx.doi.org/10.1108/IJSE-08-2015-0202

PUBLISHER

Emerald Group Publishing

VERSION

AM (Accepted Manuscript)

PUBLISHER STATEMENT

This work is made available according to the conditions of the Creative Commons Attribution-NonCommercialNoDerivatives 4.0 International (CC BY-NC-ND 4.0) licence. Full details of this licence are available at: https://creativecommons.org/licenses/by-nc-nd/4.0/

\section{LICENCE}

CC BY-NC-ND 4.0

\section{REPOSITORY RECORD}

Fraser, lan. 2016. "Sen, Marx and Justice: A Critique". Loughborough University. https://hdl.handle.net/2134/22565. 


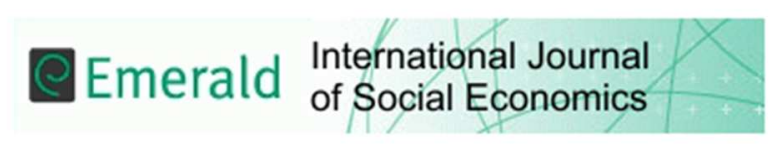

\section{Sen, Marx and Justice: A Critique}

\begin{tabular}{|r|l|}
\hline Journal: & International Journal of Social Economics \\
\hline Manuscript ID & IJSE-08-2015-0202.R1 \\
\hline Manuscript Type: & Research Paper \\
\hline Keywords: & Sen, Marx, Justice \\
\hline \multicolumn{2}{|l}{} \\
\end{tabular}

SCHOLARONE $^{\text {th }}$

Manuscripts 


\section{Sen, Marx and Justice: A Critique}

\section{Purpose (limit 100 words)}

This article offers a critique of Sen's utilisation of aspects of Marx's thought that inform his idea of justice. Marx's ideas appear in four main areas of discussion: Sen's positioning of Marx with other thinkers in his approach to justice; Marx's fluid notion of identity and its relation to social choice; the problem of transcending a subjective perspective to consider objective concerns through the impact of what Sen calls 'objective illusion'; and the issue of just redistribution.

\section{Design/methodology/approach (limit 100 words)}

I utilise a Marxian framework of analysis that engages in an immanent critique of Sen's use of Marx in his theory of justice. This is accomplished by textual analysis and a critical assessment of the analytical Marxist tradition that Sen can be seen as using in his own theories with all their inherent weaknesses.

\section{Findings (limit 100 words)}

Sen's attempt to use Marx's ideas to inform his theory of justice founder because: he groups Marx with thinkers that would not accept his desire for the abolition of capitalism and a more just society. He reduces Marx to the analytical Marxist tradition with all its inherent weaknesses. He resorts to a methodological individualist approach of choice that Marx rejects. Sen's search for positional objectivity is undermined by the power of capitalist ideology and ruling class interest. His discussion of just redistribution ignores how Marx's approach can overcome the arbitrariness that Sen presumes is inevitable when making just decisions.

\section{Research limitations/implications (limit 100 words)}

Theoretically, the article suggests that, based on immanent critique and textual analysis, Sen's use of Marx for his idea of justice is problematic most notably because Sen keeps his analysis within the framework of capitalism that Marx would reject. The implication for further research is the develonment of Marx'c nwe arnumentc nn what renctitutec a illat 
society.

\section{Practical implications (limit 100 words)}

Practically, the article raises questions about the viability of achieving justice within the capitalist system for the reasons discussed in relation to Sen.

\section{Social implications (limit 100 words)}

Socially, the article implies that far greater measures to tackle the injustices of the world are necessary than seem to be admitted to by justice theorists such as Sen.

\section{Originality/value (limit 100 words)}

I show that the use of Marx's theories to inform Sen's notion of justice, while to be welcomed, lose their efficacious power to expose the full injustice of capitalism and the need for its transcendence.

Amartya Sen won the Nobel Prize in Economics but his intellectual terrain has transcended disciplinary boundaries into the political, social and philosophical throughout his illustrious career (Morris, 2009, p. 1). Interviewed in 2009 as his magisterial The Idea of Justice was published, Sen pondered on his student days at the University of Calcutta (1951-53) and reflected that at that time 'Whether you sat in Calcutta, Saigon, Tokyo or Peking, Marx was a huge presence. Marxism was anti-imperialist and also intellectual. So I was attracted by that' (Derbyshire, 2009). Even so, as the interviewer noted, Sen was never a Marxist, being more drawn to the work of Adam Smith and in particular his Theory of Moral 
Sentiments both then and for the rest of his life. However, Sen's intellectual trajectory is more varied than that as he himself had declared three years earlier when he stated: 'I take much pride (and I think that is the right word) in the fact that my ideas are not "rootless" - they are in the "tradition" established by some very great people', and these 'intellectual instigators' include: Aristotle, Adam Smith, Mary Wollstonecraft, John Stuart Mill, Karl Marx and Kenneth Arrow (Sen, 2006, pp. 80-1). Sen's adolescent attraction towards Marx developed into the mature 'pride' of being influenced by his ideas, 'notably for teaching us that the most terrible inequalities may be hidden behind an illusion of normality and justice'. I begin by briefly examining how Marx fits into Sen's overall approach to justice and Sen's inclusion of him with other theorists. I then consider how he praises Marx for his more nuanced understanding of human identity that was not simply based on class but included other social groupings (Sen, 2010, pp. 245, 247 and 2009, pp. 120-1). Sen also cites Marx's analysis of 'false consciousness' or 'objective illusion' as a 'concept that he uses in his investigation of the underdogs in the class hierarchy' and which also informs Sen's understanding of justice (Sen, 2006, p. 82; See also, 2010, p. 163-4; 2005 , p. $8 ; 2003$, p. 322 ). Finally, I explore the conflicting claims that can arise from Sen's endorsement of Marx as part of his discussion of just distribution (Sen, 2010, pp. x, 12-15, 297; 2009, pp. 120-21; 1984, pp. $73,80,285$ and $291 ; 1982$, p. 250 and 427$)$. 
Notwithstanding these points of contact between the two thinkers, Sen's engagement with Marx on the issue of justice is stochastic and often limited. My aim in this article is, on the basis of what Sen has said above, to create a debate between Sen and Marx across these themes where he does engage with Marx and this is mainly in The Idea of Justice. I argue that the overall problem with Sen's use of Marx regarding justice is that the injustices Sen speaks of are systemically created by capitalism. If Sen or any other theorist of justice wants to use Marx then they must start with that fundamental fact. They of course cannot because they assume justice can be achieved within capitalism whereas for Marx it was only fully achievable with its abolition ${ }^{1}$ Only by relating a theory of justice to Marx's critique of capitalism can we grasp its explanatory power in overcoming the injustices Sen identifies in the world today but which his own theories cannot overcome. ${ }^{2}$

\section{Sen's Marx}

The Marx that emerges from Sen's engagement with him in his theory of justice is the Marx that has been appropriated by the analytical Marxist tradition. (For a representative sample of this approach see Roemer, 1989.) The approach is 'inspired by Marxian questions' using the 'contemporary tools of logic, mathematics...model building' and 'an unabashed commitment to the necessity for abstraction' (Roemer, 1989b, p. 3). ${ }^{3}$ Sen accordingly abstracts discusions of Marx where his critique is 
greatest, namely where Marx insists on the need to abolish capitalism and create a communist society. Sen forces Marx into a more flattened-down persona as one among many reformers who want to see more justice in the world but presume it can be achieved within capitalism as is evinced when Sen begins to explain his idea of justice further.

Regarding the Enlightenment, Sen identifies two main groupings concerning reasoning about justice (Sen, 2010, pp. xv-xvi). The first group consists of social contract theorists epitomised by Hobbes, Locke, Rousseau, and Kant. The second group consists of those who took a variety of approaches focusing on behaviour, social interactions, and institutions, and include Smith, Condorcet, Wollstonecraft, Bentham, Marx and John Stuart Mill.

Beginning with the social contract approach, Sen refers to it as '"transcendental institutionalism"' because it tries to establish just institutional arrangements for a society and contains two main aspects (Sen, 2010, p. 5). One is the search for perfect justice rather than comparing the just with the unjust, and the other is typified by trying to prioritise the right type of institutions to attain perfection without considering conceivable alternative societies (Sen, 2010, pp. 5-6). In contrast, the comparative approach, which Sen refers to as a 'realisationfocused comparison', does not limit its analysis to a transcendentalist 
search for a just society, but instead makes comparisons between existing societies or possible new ones to try to remove injustice in the world (Sen, 2010, p. 7). Sen proclaims that the difference between the two approaches is 'momentous' and notes that it is the 'transcendental institutionalism' approach that dominates contemporary political philosophy as exemplified most potently in the work of John Rawls but also in other thinkers such as Ronald Dworkin, David Gauthier and Robert Nozick (Sen, 2010, pp. 7-8). Sen associates himself with the comparative approach and states that the aim of his book is to 'investigate realisationbased comparisons that focus on the advancement or retreat of justice' (Sen, 2010, p. 8). In particular, he identifies with the analytical and mathematical discipline of social choice theory developed by Condorcet in the eighteenth century, and continued by Kenneth Arrow in the twentieth (Sen, 2010, p. xvi). Sen departs from the transcendental approach because it asks what would be perfectly just institutions, whereas the comparative approach correctly asks how would justice be advanced (Sen, 2010, p. 9). A further consequence of this is that it changes the preoccupation with institutions and rules to considering the actual realisations of justice in particular societies, which Sen suggests will require a 'radical change in the formulation of the theory of justice'.

He then contemplates objections to the role of reason in our deliberations because unreason is prevalent in the world and it is therefore optimistic to 
think reason can always prevail (Sen, 2010, pp. xvii-xviii). Sen's response is that even arguments based on unreason do have some kind of reason behind them though of a 'primitive and very defective kind' (Sen, 2010, p. xviii). His hope is that bad reasoning can be confronted by better reasoning that allows for the possibility of 'reasoned engagement' even though people may refuse to participate initially. What is important for Sen is not the claim for the universal presence of reason in everyone's thinking, but a commitment to examine 'what reasoning would demand for the pursuit of justice' while allowing for the existence of different reasonable positions (Sen, 2010, p. ix). He realises that not everyone will undertake this examination, yet reasoning is crucial in a world of unreason if we are to understand justice, according to Sen.

One of the defining characteristics of The Idea of Justice that gives the book the possibility of a wide appeal is its reasonableness and its attempt to combine diverse traditions and thinkers; but this can also be seen as one of its weaknesses. Sen admits that while sharing a point of departure with these 'diverse' theorists it does not mean that he agrees with their substantive ideas (Sen, 2010, p. 9). He contends that this should be 'obvious enough since they themselves differed so much from each other' and especially in the way they wanted the world to be. It is here that Sen's inclusion of Marx with these thinkers seems very odd as what unites all of them, but not him, is their acceptance of the capitalist system 
rather than its abolition. This is not a minor detail in the search for a more just world but a revolutionary desire that makes Marx stand apart from them. Sen also recognises that they all differ from each other but tries to force them together because they all wanted to create a more just world. But again this seems unconvincing because of the different worlds they envisaged. So it is difficult to see how Marx would feel comfortable being grouped with thinkers such as John Stuart Mill and Bentham for instance, on what constitutes a just society. When Marx mentions Mill, which is only infrequently, he does so in a derisive manner with minimal engagement with his views (Balassa, 1959, p. 147. See Duncan, 2009 for the main differences between Marx and Mill). One of Marx's main criticisms of Mill was his accommodation to and promotion of capitalism which is why Marx ironically praised him as one of the "great intellects"' whose work on political economy only further proved the 'insipid flatness of our present bourgeoisie' and attempted to 'reconcile the irreconcilable' (Marx, 1988, pp. 654 and 98). Referring to Mill's 'eclectic logic', Marx rebukes him for holding contradictory opinions and mocks his assertion that he was the new Adam Smith (Marx, p. 221). Again his work on political economy is dismissed as 'neither extensive nor profound'.

Bentham receives even further disdain as Marx dismissed him as a 'homespun manufacturer of commonplaces' and rejected outright his principle of utility because it 'assumes that the modern petty bourgeois, especially the English petty bourgeois, is the normal man' (Marx, 1988, pp. 758-759, n. 51). By applying his principle of utility to humans, 
Bentham does not realise that he first needs to deal with 'human nature in general, and then with human nature as historically modified in each epoch'. Marx concludes that Bentham is the epitome of 'bourgeois stupidity'. So including Marx with these other thinkers ignores his complete rejection of their acceptance and defence of bourgeois society and the continuation of capitalism. The eclecticism that Sen desires because he wants wide agreement and inclusivity to make his theory of justice viable simply forces Marx into the company of thinkers that his own approach would reject because it is based on abolishing rather than preserving capitalism, which is an outcome that Sen would not accept. This is further exacerbated when we now consider Sen's discussion of Marx on identity and social choice.

\section{Identity and Social Choice}

For Sen, Marx realised that class analysis was important but that it needed to be enhanced by recognising that people are members of a number of social groupings. Sen cites as evidence The Critique of the Gotha Programme where Marx states that the mistake of the United Workers' Party of Germany was that it considered workers only as workers and '"nothing more is seen in them"' (Sen, 2010, p. 247; Marx). Sen relates this to the current intellectual climate where individuals can be identified in one social category to the exclusion of all others, be it a Muslim, a Jew and so on. For Sen, following Marx, 'individual human 
beings with their various plural identities, multiple affiliations and diverse associations are quintessentially social creatures with different types of societal interactions' (Sen, 2010, p. 247). Consequently, seeing a person as a member of one social group ignores the 'breadth and complexity of any society in the world' (Sen, 2010, p. 247).

Sen endorses Marx further because he grasps how individuals are social beings that make choices and perform actions in a process of societal relations (Sen, 2010, p. 245). Sen mentions the Economic and Philosophical Manuscripts here for support (Marx, 1959, p. 104), but Marx does not talk about the issue of choice, although he certainly understands the self as a social self. Interestingly, Sen also references John Elster (1985) simultaneously with Marx but strangely suggests that the 'presence of individuals who think, choose and act - a manifest reality in the world - does not make an approach methodologically individualist' (Sen, 2010, p. 245). I say strangely because Elster's rational choice Marxism, part of the analytical Marxist tradition discussed earlier, is based on the premise of methodological individualism that Sen's negative reference to this approach as a 'feared beast' seems to ignore (See, Elster, 1985, pp. 5-8). Sen rightly rejects the 'illegitimate invoking of any presumption of independence of the thoughts and actions of persons from the society around them' that results in methodological individualism, but seems unaware that is what Elster's approach does. As Elster explains, 
the notion of methodological individualism means that 'all social phenomena - their structure and their change - are in principle explicable in ways that only involve individuals - their properties beliefs and their actions', resulting in a 'form of reductionism' (Elster, 2010, p. 5). For Marx, this is mistaken because individuals are not isolated otherwise they would be the Robinsonades that he was critical of Smith and Ricardo as positing as a 'true' understanding of individuals, rather than how they really are: social beings. Smith and Ricardo imagine individuals in this way to account for the non-social atomised beings that were created by the development from feudalism to industrial capitalism (Marx, 1973, pp. 83-85).

Sen suggests he surmounts this problem by embracing Marx's understanding of people as being members of multiple groups, but Sen descends into the Robinsonade individualism that Marx condemns by proposing that only individuals are concerned with justice because practical reasoning is carried out by individuals and not by groups (Sen, 2010, pp. 246-7; Deneulin, 2011, pp. 792-793). Sen sees group membership as militating against our capacity for reasoning and deliberating about justice because it is subsumed in the level of collaboration that people have with each other, and can result in a limitation on their capacity for deliberation. Yet this dislocates humans from the structured world they inhabit when they make their decisions 
and which can therefore reinforce instances of injustice. Just as it is incorrect to engage in reductionism down to the individual, so it is illegitimate to engage in a subsumption of that individual by being a member of one group. Sen is proposing a false dichotomy based on an undialectical understanding of the self, which, when grasped dialectically, operates through many different discourses for understanding the world. (See Fraser, 2007 for a dialectical understanding of the self in Marx.)

Sen then tries to incorporate Marx into the social choice tradition (Sen, 2010, pp. 410-411). Sen reflects that social choice theory from Condorcet to Kenneth Arrow has influenced his own approach 'on making evaluative comparisons over distinct social realisations'. He maintains that 'in this respect it has similarities with those in the comparative tradition' of which Marx is designated as being a member along with Adam Smith, Jeremy Bentham and John Stuart Mill, as we saw earlier. Sen observes that the value of social choice theory is that it is 'deeply concerned with the rational basis of social judgements and public decisions in choosing between social alternatives' (Sen, 2010, p. 95). Just how this relates to Marx is never explained by Sen but it is difficult to interpret Marx within this tradition given it again focuses on the issue of choice and does not problematise the notion of rationality. Sen presumes a reasonableness that dissipates when confronted with the ideology of class privilege and interest once choices are located within the structure of capitalism. 


\section{Objective Illusion}

Marx also informs Sen's discussion of illusion when considering the epistemological need to 'transcend the limitations of our positional perspectives' in the search for justice and the rooting out of injustice (Sen, 2010, p. 155). Sen realises that the latter can be difficult given our inability to always comprehend what is happening in the things that we see, an inability which arises from the limitations of our own perspective. Sen explains these 'positional variations of observations' by considering a claim that the sun and the moon look similar in size (Sen, 2010, p. 156). He sees this as a positional claim even though it is not made explicit, because in reality the view is made from the position of the earth. A person in a similar position could confirm the statement but another person could also make a claim about how things might appear from a different position, where the sun and the moon would not look similar in size, a position which is not in tension with the previous statement.

Sen argues that 'positional objectivity' requires interpersonal invariance when the observational position is fixed, and this is compatible with what is seen from different positions. The objective aspect is that any person adopting a particular position will make the same observations, and thereby the two aspects of positional variability are not entirely subjective (Sen, 2010, pp. 157-158). So an observational statement is not necessarily a statement about the working of a person's psyche because it 
also establishes physical qualities, such as the size of the sun and the moon, which are independent of anyone's mind (Sen, 2010, 158). For Sen, this raises the issue of positional objectivity that can differ in certain circumstances, as in relation-based personal responsibilities with regard to prioritising one's children, for example, and ignoring the needs of other children. Nevertheless, the need for a better theory of justice must overcome this limitation and try to take a "positionally unbiased"' approach (Sen, 2010, 160-161). This would entail recognising, for example, that other people's children are also to be taken into account when making decisions in relation to your own offspring (Sen, 2010, p. 161). Sen specifies that this involves a search for a 'position-independent' or a 'transpositional understanding' of the world, that goes beyond positional prejudice and sectional favouritism.

Sen explains that even when a position-independent view is taken there are still obstacles in achieving an unbiased comprehension (Sen, 2010, p. 161). People can find it difficult to transcend their positionally limited visions as is the case, for instance, in societies that have a long history in subordinating women so it becomes a cultural norm and an accepted way of life (Sen, 2010, p. 162). One way to counter this could be to consider a different society where women are allowed to flourish rather than being discriminated against. To do so means adopting a position of "'open impartiality"' or Adam Smith's notion of the impartial spectator that seeks 
out perspectives both near and far. (For a critique of Sen's use of Smith on this issue, see Fraser, 2012.) Sen realises that there can be severe difficulties in overcoming prejudices in certain societies, especially as some women will accept their subordination via a 'faulty reading of local observations'. However, positional objectivity offers a 'scientific contribution' by exposing the illegitimate application of positional comprehension, instead of a transpositional understanding (Sen, 2010, pp. 162-163).

Sen considers the notion of "'objective illusion"', which he maintains is used in Marxist philosophy, and can be interpreted in terms of positional objectivity (Sen, 2010, p. 163). He argues that the 'concept of objective illusion' appears not just in Marx's philosophical writings but also in Capital, Volume 1, and Theories of Surplus Value, although Sen does not offer any page references to support this. He specifies that one of Marx's main concerns was to show how the supposedly fair exchange in the labour market in capitalism was illusory, even though the workers themselves, who are 'robbed of part of the value of their products', believed otherwise. So 'an objective illusion...is a positionally objective belief that is, in fact, erroneous in terms of transpositional scrutiny' and contains the idea of a positionally objective belief and the transpositional diagnosis that the belief is in fact mistaken. To illustrate this further, Sen 
quotes at length the analytical Marxist G. A. Cohen on the notion of objective illusion in Marxian theory (Cohen, 1978, pp. 328-9).

Cohen proposes that from a Marxist perspective on the natural sciences, the senses mislead us when confronted with the constitution of the air and the movements of heavenly bodies. He reflects that if someone could decipher, through breathing, different components in the air then they would have a nose that did not function as a normal human nose does. Similarly, a person who said that they could see the sun as stationary and the earth as rotating would be suffering from some form of impaired vision. Cohen asserts that visual experiences are like mirages rather than hallucinations. If a person does not see a mirage under the right conditions then there is something wrong with the person's vision as their 'eyes have failed to register the play of lights in the distance'.

Sen deduces from this discussion that the observations are positionally objective but also misleading or mistaken in terms of other more compelling criteria of truth that can be invoked by going beyond positional perspectives (Sen, 2010, 164). He concludes by stating that Marx's own use of objective illusion was mainly for class analysis and this led him to investigate 'what he called "false consciousness"'. Sen then abruptly leaves Marx and examines objective illusion in the health situation in developing economies through the self-perception of morbidity and 
gender discrimination (Sen, 2010, pp. 164-167). Marx, though, never used the term 'false consciousness' to understand the nature of objective illusion in Sen's sense of the term structuralist Marxism was mainly responsible for imputing this interpretation onto Marx (See for example, Althusser, 1971) but, as evinced above, it was also adopted by analytical Marxists such as Cohen. Marx used objective illusion to expose the ideological nature of the way the capitalist system is explained and commonly understood. Moreover, while Marx rejects arguments about justice and normative ethics, albeit not in a convincing manner given the passion with which he derided the inhumanity of capitalism, he explains scientifically how exploitation and oppression are a systemic creation within that system. (For the normative dimension to Marx's work see Wilde, 1998 and 2001 and Thompson, 2015) So if Sen as a modern justice theorist wants to use Marx to aid his theory, then he needs his analysis to be focused from the outset on these outcomes that are intrinsic to capitalism. Unfortunately, Sen is unable to do this and undermines any proposals he has for creating a more just world.

For Sen, overcoming objective illusion and achieving positional objectivity is also crucial as it has a special role for public reasoning when trying to understand demands for justice (Sen, 2010, p. 167). He notes how public reasoning can be limited in practice because people can misread the world they live in, especially if the 'powerful influence of positionality has an 
obscuring role in that social understanding' (Sen, 2010, p. 168). Sen recognises that special attention should be devoted to trying to overcome the difficulties that can arise when trying to assess issues of justice and injustice. The role of positionality is 'crucial in interpreting systematic and persistent illusions that can significantly influence - and distort - social understanding and the assessment of public affairs'.

Sen has an optimistic view that we can achieve this objective positionality, but he does not comprehend that in a capitalist system one person's objective positionality is another person's objective illusion. To illustrate this, one only has to reflect, for example, on the way the UK Coalition government led by David Cameron responded to the financial crash that occurred in 2008 . The position taken by the Coalition was to make excessive cuts to public expenditure and public services to reduce the budget deficit, causing mass unemployment and severe hardship for some of the most vulnerable people in society; a clear case of injustice. The mantra that covers these policies is that 'we are all in this together' and must suffer austerity for the national interest. This is then perpetuated in a generally suppliant and sympathetic media as the conventional wisdom with little riposte from the established Opposition. The powerful influence of Cameron's 'positionality' aided by the media is certainly obscuring 'social understanding', because this is not the only way to respond to the crisis, as more enlightened theorists have indicated 
from both non-Marxist (Stiglitz, 2010) and Marxist perspectives (Blackburn, 2011; Streeck, 2012).

Sen's desire that we can overcome positional illusions by 'broadening the informational basis of evaluations' ignores the power of the ideology of capitalism that Marx's analysis can expose, which is why he concentrated on class issues. For Marx, the ruling ideas in any society are the ideas of the ruling class (Marx and Engels, 1976, p. 59) and what we are seeing in the case of UK austerity is ideology posing as positional objectivity in the service of capital, and financial capital in particular. Practical reasoning is never going to make Cameron and his successors change their minds. Something far stronger is needed for that.

Sen is correct in praising Marx for identifying the objective illusions that permeate capitalism, but Marx did so to expose the naked truth about the system. Focusing on the way capitalism inverts reality and presents the world in the opposite way to how it really operates, exposes the classbased nature of the system. Marx's critique shows how the powerful can conceal their own actions in pursuing their own interests, while making it appear they are doing it for the good of everyone else.

\section{Just Redistribution}


Marx also influences Sen's discussion of what constitutes a just distribution of goods in society. Sen observes that Marx recognised in The Critique of the Gotha Programme (1875), the 'inescapable conflict' between the argument for eliminating the exploitation of labour on one side and for allocating according to needs on the other (Sen, 2010, p. x). In the first case, the relation is to the justness of getting what can be seen as the product of one's efforts', whereas in the second case it relates to the demands of distributive justice. So Marx is important for recognising conflicting claims of justice and that is one of the main features of Sen's own theory.

Sen explores this issue with his example of the three children, Anne, Bob and Carla, who are quarrelling over who should get a flute (Sen, 2010, pp. 12-15). Sen's use of highly abstract and hypothetical examples is often unconvincing and why The Idea of Justice has been criticised for offering few concrete cases of how its theory relates to practice in the real world (Deneulin, 2011, p. 790). Engaging with them means surrendering to the logic and assumptions immanent in that type of approach. I do so here on the understanding that the flute example is a priori flawed because it strips out the capitalist world and all the respective power relations belonging to that system where these decisions are made. With that said let us consider Sen's deliberations. 
Sen ruminates on varying scenarios for each of the children making claims on the flute: Bob, due to his poverty compared to the others, Carla, as she has made it with her own labour, and Anne who is the only one who can play it. Sen considers these competing claims from a Marxist and libertarian perspective and deduces that both would give the flute to Carla because they share the idea of the right to the fruit of one's labour (Sen, 2010, p. 14). He sees this as uniting these seemingly opposed perspectives 'no matter how uncomfortable each might be in the company of each other'. Commenting on this further in a footnote, Sen argues that Marx came to be sceptical of the right to one's labour which, in The Critique of the Gotha Programme, he described as a '"bourgeois right"' to be ultimately rejected with a "'distribution according to needs"' being put in its place. (Sen refers us to Sen, 1975, Ch. 4 where there is no mention of Marx, and to an eclectic collection of essays by the analytical Marxist G. A. Cohen, 1988.)

There is some confusion in Sen's account here because Marx talks about these forms of distribution in two contexts not one, and they are not applicable to the example of the distribution of the flute. In The Critique of the Gotha Programme, Marx's discussion is firstly about the lower phase of communist society that is 'still stamped with the birthmarks of the old society from whose womb it emerges', namely capitalism (Marx, 1983, p. 17. For a more detailed discussion of Marx's notion of 
communism see Berki, 1983). Workers would still be imbued with the way they worked under capitalism and demand to be rewarded for the labour they had put into the production of goods. Workers at this stage of communist society receive back 'after the deductions have been made' exactly what they have given to it in terms of the expenditure of their labour. They then receive certificates for the amount of labour they have put in, which they can use to claim their portion of the means of consumption. Marx's reasoning is that if the workers were given everything back that they had produced, then there would be no possibility for further developments of the productive forces and no general investment in society.

As Sen correctly realises, this is what Marx refers to as a 'bourgeois right', because all individuals are 'unequal' in that they differ in terms of their physical and mental capacities and so can labour for a longer or shorter time as the case may be. They may also have dependents, so inequality is present at this stage of communist society (Marx, 1983, p. 18). What distinguishes Marx and Marxists from libertarians therefore is the necessity for workers to give up a portion of what they have expended for the good of society. A libertarian, on the other hand, would not agree with the 'deductions', as they would be seen as infringements of the right to keep the whole fruits of one's labour (see for example, Nozick, 1991). Despite what Sen suggests, these two positions of Marxism and 
libertarianism cannot be elided in the way they understand desert based on the labour expended. The libertarian principle that workers should get the full fruits of their labour would result in a society based on selfinterest and egoism, whereas the Marxist principle that workers should give something back would be far more communal. This would result in two quite distinct societies resting on two different notions of what is just.

In the higher stage of communist society, the undesirable principle of calculating on the basis of a worker's contribution will be replaced, as Sen correctly notes, by a distribution based on Marx's edict of 'from each according to ability to each according to need' (Marx, 1983, p. 19). ${ }^{4}$ The emphasis now is on what your needs are regarding the differences between people rather than what you have put in to the production process as in the earlier stage of communist society. Sen fails to relate this back to his hypothetical example even though it can be slightly more appropriate to do so in this case. If communist society is based on doing what you are able to do and being rewarded on the basis of need, then who should get the flute? The right to the flute cannot be because you have made it, so it cannot go to Carla. The greatest need is Bob's, because, Sen informs us, he has fewer toys than the other two. Anne's claim that she should get it because she is the only one who can play the flute cannot trump the need of Bob. In a communist society, one might hope that Anne would help Bob to learn how to play the instrument. 
Nonetheless, this is the problem stated earlier of being drawn into the logic of Sen's examples because in this highest stage of communist society Bob's poverty would not arise because the development of the productive forces was predicted by Marx, rightly or wrongly, to ensure a society of abundance which would allow the flourishing of human beings (Marx, 1976, p. 49 and 1973, p. 325). This of course could still mean that Anne might help Bob to play the flute so he too can develop the required skill. So despite Sen's protestations to the contrary, it is possible to ground a decision here that does not descend into 'arbitrariness'. Marx's hope, one assumes, would be that Carla should see this as the right outcome for the greater good of society and, in doing so, would transcend the 'narrow horizon of bourgeois right' in a communist society where 'all the springs of cooperative wealth flow more abundantly' (Marx, 1983, p. 19).

Additionally, the flute is not a commodity in Marx's sense of the term because, in this example at least, it is not an object that is bought and sold on the market and is instead for immediate consumption. Moreover, where did Carla get the wood to make the flute? Why was the wood not available for the other two to try to make a flute? How did Carla and Anne have more toys than Bob initially? In a communist society, Bob would not have fewer toys, so this would also change the distributive outcome, as the flute would go to Anne who needs it most because she has got a 
talent that she cannot realise. As mentioned earlier, this is the danger in Sen's use of hypothetical and relatively abstract examples as they can lead to unrealistic and unconvincing conclusions.

Sen also considers just distribution in the instance of the three children quarrelling over the flute when discussing equality of capability (Sen, 2010 , p. 297). Despite recognising the importance of equality, he rejects it when it is aligned to capabilities because it does not always "trump" all other weighty considerations' with which it might conflict (Sen, 2010, p. 295). He understands the importance of freedom when assessing claims for equality and evaluating personal advantages but insists that there are 'other demands on distributional judgements, which may not be best seen as demands for equal overall freedom for different people' (Sen, 2010, p. 297).

Relating this to the example of the flute and the three children, Sen contends that the child who has made the flute, (it was a female, Carla, but Sen mistakenly refers to her as 'he'), deserves 'just recognition' for doing so (Sen, 2010, p. 297). Equality of capability would imply that her claim would be trumped by ensuring Anne and Bob have the resources necessary so they can make the flute with the possible detriment to the resources given to Carla. However, for Sen, such a claim 'cannot be readily dismissed' because a special status should be attached to the 
efforts and rewards associated with labour that could undermine the case for equality of capability. He notes how the literature on the exploitation of sweated labour and the unjust rewards received by those doing the "'real work"' has strong links with this perspective, particularly in the Marxist tradition (Sen, 2010, p. 297 and 442, n.7). Sen is of course correct that this claim cannot be readily dismissed, but it does need to be reasoned more carefully.

Sen is suggesting that Carla has the right to the fruits of her labour as she is the one who has made the flute. Sen tries to justify this further by citing the injustice of sweated labour but his reasoning here is flawed. The weakness of the hypothetical example in suggesting that Carla could have a claim to keep the flute as she has created it again ignores, as I mentioned earlier, how she came to have the resources to make it initially and the other children did not. This is the problem with hypothetical examples, and trying to link this claim to the reality of the exploitation of sweated labour does not help the argument either. Is Sen suggesting that these workers should retain the whole of the surplus that they are creating? If so, then following Marx means we have to reject this claim again because even in the lowest stage of communist society part of any surplus created must go back into investment for society as a whole. Sen seems to slip into a libertarian perspective that denies the need for 
communal distribution of resources and rewards to create a more just society.

\section{Conclusion}

Sen's 'pride' in Marx as an 'intellectual instigator' for his exploration of the idea of justice has centred around four themes. The first was Sen's positioning of Marx in Sen's own approach to justice by grouping him with thinkers who would not accept his desire for the abolition of capitalism, as Sen himself would not. Also, the Marx that Sen presents to us is the one appropriated by the analytical Marxism tradition, a diluted Marx reduced to unrealistic abstractions that consider issues of justice without locating them in the systemic nature of the capitalist system. Sen's discussion of identity and social choice, although correctly grasping Marx's notion of multiple selves, ultimately falls back into a methodological individualist approach of choice that Marx rejects, and could not form the basis of a just communist society. As regards the issue of objective illusion, Sen's search for positional objectivity (so we can come to agree on what is just or unjust through practical reasoning) is undermined by the power of capitalist ideology and ruling class interest. Finally, Sen's utilisation of Marx's redistributive theory mistakenly elides Marx with libertarian perspectives which are based on very different notions of what is just in relation to the reward for labour expended. Sen's retreat into the hypothetical abstract world is symptomatic of analytical Marxism and its 
inherent weaknesses. This retreat fails to make a distinction between Marx's different phases of communist society, which has major implications for what is and what is not a just distribution according to Marx, and which is not arbitrary as claimed by Sen. Consequently, failing to link his idea of justice with Marx's rejection of capitalism means Sen's desire to 'eliminate...remediable injustices' (Sen, 2010, p. vii) although to be welcomed, is more akin to building 'castles in the air' (Marx and Engels, 1987, p. 117).

\section{Notes}

I would like to thank Tony Burns, Colin Tyler, David Weinstein, Lawrence Wilde and the anonymous reviewers of this journal for their helpful comments on a previous version of this article.

${ }^{1}$ Sen's fellow justice theorist Martha Nussbaum also does this in her selective use of Marx. See Nussbaum (2006). For a Marxist critique of her positon and one-sided use of Marx see Wilde (2012).

${ }^{2}$ This pertinent point is made in a perceptive article by Deneulin but is not developed as I have done here (See Deneulin, 2011, p. 796). 
$\overline{{ }^{3} \text { For a robust rebuttal of this approach as not being in any way Marxist }}$ because its methods are bourgeois and its politics reactionary see Wood, 1989, with whom I agree.

${ }^{4}$ There has been much dispute over the origin of this phrase with some suggesting it preceded Marx but for a rebuttal of this see 'Notes from the Editors', 2014.

\section{References}

Althusser, L. (1971), Lenin and Philosophy and other Essays, New Left Books, London.

Balassa, B. A. (1959), 'Karl Marx and John Stuart Mill', Weltwirtschaftliches Archiv, Bd. 83.

Berki, R. N. (1983), Insight and Vision. The Problem of Communism in Marx's Thought, J. M. Dent, London.

Blackburn, R. (2011), 'Crisis 2.0', New Left Review, 72, November/December, pp. 33-62.

Cohen, G. A. (1978), Karl Marx's Theory of History: A Defence, Oxford, Clarendon.

Cohen, G. A. (1988), History, Labour and Freedom: Themes from Marx, Oxford, Clarendon.

Deneulin, S. (2011), 'Development and the Limits of Amartya Sen's The Idea of Justice', Third World Quarterly, 32, 4, pp. 787-797. 
Derbyshire, (2009), 'The NS Profile: Amartya Sen', New Statesman, 23

July. Available at: http://www.newstatesman.com/international-

politics/2009/07/sen-interview-smith-income. Accessed 9 February 2016.

Duncan, G. (2009), Marx and Mill. Two Views of Social Conflict and Social

Harmony, Cambridge, Cambridge University Press.

Elster, J. (1985), Making Sense of Marx, Cambridge University Press, Cambridge.

Fraser, I. (2007), Dialectics of the Self: Transcending Charles Taylor, Imprint Academic, Exeter.

Fraser, I. (2012), 'Distant Voices: Amartya Sen on Adam Smith's Impartial Spectator', Culture and Dialogue, 2, 2, pp. 51-71.

Marx, K. (1959), The Economic and Philosophical Manuscripts of 1844, Progress Publishers, Moscow.

Marx, K. and Engels, F, (1976), The German Ideology, in K. Marx and F. Engels, Collected Works. Volume 5, Lawrence and Wishart, London.

Marx, K. and Engels, F, (1987), The Communist Manifesto, Penguin, Harmondsworth.

Marx, K. (1973), Grundrisse, Pelican, London.

Marx, K. (1988), Capital. Volume 1, Penguin, Harmondsworth.

Marx, K. (1983), The Critique of the Gotha Programme, in K. Marx and F. Engels, Selected Works. Volume 3, Progress Publishers, Moscow.

Morris, C. W. (2009), 'Introduction' to C. W. Morris (ed.), Amartya Sen, Cambridge University Press, Cambridge. 


Notes from the Editors (2014), Available at:
http://monthlyreview.org/2014/07/01/mr-066-03-2014-07 0/. Accessed 22 August 2016.

Nozick, R. (1991), Anarchy, State and Utopia, Blackwell, Oxford.

Nussbaum, M. (2006), Frontiers of Justice: Disability, Nationality, Species Membership, Harvard University Press, Cambridge, MA.

Roemer, J. (ed.) (1989a), Analytical Marxism, Cambridge University Press, Cambridge.

Roemer, J. (1989b), 'Introduction' in Analytical Marxism, Cambridge University Press, Cambridge.

Sen, A. (1975), On Economic Inequality, Clarendon, Oxford.

Sen, A. (1982), Choice, Welfare and Measurement, Blackwell, Oxford.

Sen, A. (1984), Resources, Values and Development, Blackwell, Oxford.

Sen, A. (2005), 'Mary, Mary, Quite Contrary!,' Feminist Economics, 11, 1.

Sen, A. (2006), 'Reason, Freedom and Well-Being', Utilitas, 18, 1.

Sen, A. (2009), Inequality Reexamined, Clarendon, Oxford.

Sen, A. (2010), The Idea of Justice, Penguin, London.

Sen, A, Bina, A, Humphries, J and Robeyns, I. (2003), 'Continuing the Conversation,' Feminist Economics, 9, 2-3.

Stiglitz, J. (2010), 'Dangers of Deficit-Cut Fetishism', The Guardian, 7 March. Available at:

http://www.guardian.co.uk/commentisfree/2010/mar/07/deficitfetishism-government-spending. Accessed 31 March, 2012. 
Streeck, W. (2012), 'Markets and Peoples', New Left Review, 73, January/February, pp. 63-73.

Thompson, M. J. (2015) (ed.) Constructing Marxist Ethics, Brill, Leiden. Wilde, L. (1998), Ethical Marxism and its Radical Critics, Macmillan, Houndmills.

Wilde, L. (2001) (ed.), Marxism's Ethical Thinkers, Palgrave, Houndmills. Wilde, L. (2012), 'Marx, Morality and the Global Justice Debate', in M. Johnson (ed.), The Legacy of Marxism. Contemporary Challenges, Conflicts and Developments, Continuum, London.

Wood, E. M. (1989) 'Rational Choice Marxism. Is the Game Worth the Candle?', New Left Review, 1/177, September-October. 